\title{
DECREASED COPPER LEVEL IN THE BLOOD SERUM OF MALE STUTTERERS AND THE OCCURRENCE OF THE VIBRATIO BREVIS PHENOMENON
}

\author{
Josef Pešáka , Jaroslav Opavskýb \\ a Department of Biophysics, Medical Faculty, Palacký University, Olomouc, Czech Republic \\ $b$ Department of Physiotherapy and Pain Therapy, Faculty of Physical Culture, Palacký University, Olomouc, Czech \\ Republic
}

Received July 15, 2000

Key words: Stuttering / Copper / Blood serum / Vibratio brevis phenomenon

The blood serum copper level and the phonation start were investigated in sixteen male subjects with developmental stuttering (mean age $=25.8$ years). A statistically significant decrease in blood serum copper level was revealed in the stutterers under study. The differences between their mode and mean values and that of the control group were $4.6 \mu \mathrm{mol} / \mathrm{l}$ and $3.1 \mu \mathrm{mol} / \mathrm{l}$, respectively. The negative linear regression between the copper level in serum and the vibratio brevis phenomenon was registered in the stutterers under study. A decreased copper level can be involved in the biochemical abnormalities of male developmental stutterers and it can be included among the factors participating in pathophysiology of an uncertain phonation start.

\section{INTRODUCTION}

Approximately 1-2 per cent of school-aged children stutter and the prevalence of developmental stuttering is about one per cent of the adult population ${ }^{1}$.

Different neurophysiological and neurovascular factors ${ }^{4,8,13}$ play a role in individual cases of stutterers. In addition to the neurophysiological abnormalities, there are some biochemical ones, 3, 5, 9, 11, 12, which can be involved in developmental stuttering. Low serum copper level was found in subject with dysarthria with scanning speech, gait disturbances and involuntary movements ${ }^{6}$, and abnormal copper metabolism was described in subjects with spastic dysarthria, dementia, impaired vertical eye movements and gait difficulties ${ }^{14}$. Well-known is an association between the abnormal copper metabolism and neurological inclusive speech disorders in Wilson's disease.

Therefore, the study was focused on the biochemical blood findings in stutterers. The aim of the study was to investigate the blood serum copper level, serum ceruloplasmin and serum albumin, and the levels of several other chemical constituents of blood (calcium, magnesium, iron and zinc). Furthermore, a secondary aim of the study was to evaluate the relationship between the blood serum copper level and the presence of an uncertain phonation start, the phenomenon, called by Pešák and Urbánek ${ }^{7}$ vibratio brevis in stutterers. This phenomenon appears in these subjects even in cases their phonation manifestations are apparently fluent. According to Pešák and Urbánek ${ }^{7}$, vibratio brevis can be discovered in a high percentage (approximately 97 per cent) of stutterers while in non-stuttering subjects its presence is much lower (below 10 per cent).

\section{METHODS}

\section{Subjects}

Sixteen patients with developmental stuttering served as investigated subjects. Their age range was from 14 to 46 years, with the mean age of 25 years 10 months. No subject suffered from a metabolic disease or from any other serious somatic or neurological illness. On the same day the samples of blood were taken by venipuncture for the biochemical investigations, and the registration of the vibratio brevis phenomenon was performed.

The control group, sex- and age-matched, included sixteen male non-stuttering subjects, without serious metabolic or neurological diseases, age range from 17 to 43 years, with the mean age of 30 years 8 months. These subjects were submitted to the same investigation procedures.

The study design adhered to the Helsinki Declaration.

\section{Copper in the blood serum analysis}

The samples of blood were taken by venipuncture at 8 a.m. The total amount of blood obtained from each subject under study was approximately $15 \mathrm{ml}$. The testtubes had been thoroughly washed in diluted hydrochloric acid before the examination. The samples of blood were centrifuged and evaluated by means of an atomic absorption spectrophotometer UNICAM SP 90. The blood serum copper level was expressed in $\mu \mathrm{mol} / \mathrm{l}$. (Normal range 12.5-21 $\mu \mathrm{mol} / 1$.)

\section{Analysis of other blood constituents}

Serum ceruloplasmin was estimated with the use of immunoturbidimetric method (Boehringer Tina-quant). 
Serum albumin, calcium and iron levels were evaluated photometrically (HITACHI 917). Erythrocyte and serum magnesium and total serum zinc were determined by means of an atomic absorption photometer.

\section{Registration of vibratio brevis phenomenon}

This phenomenon was described by Pešák and Urbánek $^{7}$ and named vibratio brevis . Tesla OPD 602 oscilloscope, equipped with Tesla OPJ 619 device for the registration of very fast mechanical events was used for the registration of the uncertain phonation start, occurring in stutterers in the prephonation phase, and being denoted, as mentioned above, as vibratio brevis. The time base used was $80 \mathrm{~ms}$. The stutterers repeated 10 times the vowel [a:]. The presence of vibratio brevis during the ten vowel repetitions was evaluated. The normal finding is demonstrated in Fig. 1 and the acoustic record of a typical vibratio brevis is demonstrated in Fig. 2.

\section{Statistical analysis}

The results are presented as modes, means and standard deviations. Statistical comparisons were based on Mann-Whitney test. The relationship between variables was assessed by means of the correlation coefficient by Pearson.

\section{RESULTS}

The blood serum copper level and its distribution in a group of stutterers and in control group is shown in the graph (Fig. 3). The most frequently occurring value (the mode) of the blood serum copper level in stutterers was $13.6 \mu \mathrm{mol} / \mathrm{l}$. The mean value was $14.1 \mu \mathrm{mol} / \mathrm{l}$, standard deviation was $2.1 \mu \mathrm{mol} / \mathrm{l}$, range $10.7-18.2 \mu \mathrm{mol} / \mathrm{l}$. The statistically significant dependence between the decrease of the blood serum copper level and the severity of stuttering was not proved.

The mode value of the blood serum copper level in the sex- and age-matched control group involving 16 non-stuttering subjects was $18.2 \mu \mathrm{mol} / \mathrm{l}$. The mean value and standard deviation of the serum copper level in this group was found to be $17.2 \mu \mathrm{mol} / 1$ and $2.3 \mu \mathrm{mol} / 1$, respectively. The range of the serum copper level was in this group 13.2-20.7 $\mu \mathrm{mol} / \mathrm{l}$. The differences both in mode and in mean values between the stutterers and this group of healthy subjects were statistically significant $(\mathrm{p}<0.001$ and $\mathrm{p}<0.001)$. It was found that the stutterers with the more severe language difficulties had the serum copper level around or below the lower limit of the control non-stuttering group.

Serum ceruloplasmin and albumin levels were in all the subjects under study within normal limits. For the other blood constituents, all the findings in the nonstuttering group were within the normal ranges. In contrast with it, the erythrocyte magnesium was decreased in the group of stutterers in six cases and increased in two cases (ranges 1.3-1.9 mmol/l). Serum iron level was in three subjects increased and in another three decreased in this group (ranges 14.0-25.3 $\mu \mathrm{mol} / \mathrm{l}$ ). Other biochemical findings were found in stutterers under the study within the normal ranges.

The vibratio brevis phenomenon ${ }^{7}$ was detected in all the stutterers under study and in none member of the control group.

The correlation between serum copper level and the frequency of vibratio brevis, as a manifestation of the uncertain phonation start, was assessed by means of the Spearman rank correlation coefficient. The correlation coefficient was $r=-0.5678(p<0.0279)$. The registered manifestation of the uncertain phonation starts expressed by the presence of the vibratio brevis phenomenons were regarded as a dependent variable, and the decrease of the serum copper level as an independent variable. The blood serum copper level and the number of the vibratio brevis phenomenon were negatively correlated in the group of stutterers under study (Fig. 4).

\section{DISCUSSION}

A great number of theories about the origin of developmental stuttering were formulated. These are based both on neurophysiological and on biochemical abnormalities in stutterers. But the unifying theory about its pathophysiology was not yet accepted.

Regional cerebral blood flow abnormalities ${ }^{8}$ and abnormalities recognized in PET studies ${ }^{4}$ support the vascular and metabolic origin of this disorder. Various biochemical abnormalities represent different pathophysiological factors involved in stuttering (e.g., , $^{3,5,9,10,11}$ ).

A decrease of the magnesium-ion concentration was described in biochemical studies focused on blood ion levels in stutterers ${ }^{11,12}$. Inconstant abnormalities in the erythrocyte magnesium level were revealed in eight of sixteen stutterers under the study (in six of them a decrease and in two others an increase of this blood chemical constituent). These findings confirm the description of magnesium abnormalities in stutterers ${ }^{12}$. Contrarily, no decrease of the serum magnesium level was found in the present study in the group of the stutterers.

The main target of this study was to investigate the serum copper level in male stutterers. A statistically significant decrease of this blood chemical constituent (both for mode and for mean values, $\mathrm{p}<0.001$ ) was proved by atomic absorption spectrophotometry in the group of stutterers in comparison with the non-stuttering subjects under the study. Until now, the decrease of the serum copper level in male stutterers has not been described. Whether this finding is sex-dependent could not be stated, because the group of stutterers under study involved only male subjects. Similar slightly lowered serum copper level was discovered in patients with dysarthria with scanning speech ${ }^{6}$ and abnormal copper metabolism was described in subjects with spastic dysarthria in conjunction with next other disturbances ${ }^{14}$. In 
all these diseases or disorders the low serum copper level or an abnormal copper metabolism were described only as a primary observation. The role of an altered copper metabolism was not in these observations explained and it was not clear, if the copper in these situations had a special pathophysiological meaning or if it was described only as an epiphenomenon.

The interrelationship of stuttering and the presence of the phenomenon called "vibratio brevis" was described by Pešák \& Urbánek7. In another, hitherto unpublished study by the same authors focused on copper metabolism it was discovered in children who stutter, that the decreased serum copper level was associated with the more frequent clonic manifestations of stuttering, while the copper levels within the normal range were revealed more frequently in association with the tonic ones.

On the basis of the results obtained in the present study the relationship between the biochemical (serum copper level) and biophysical findings (registered as mechanical events associated with an uncertain phonation start) in male stutterers was established. The number of the onsets of the recently recognized phenomenon, called vibratio brevis ${ }^{7}$, was negatively correlated with the blood serum copper level in a studied group. This supports a significance and the association of the recognized abnormality of the blood serum copper level with the uncertain phonation start in these subjects.

The results presented in this study suggest that a slight decrease of the copper level in the blood serum can be included among the chemical abnormalities recognized in male stutterers and that it can be added to the spectrum of the factors influencing the neurophysiological and mechanical events associated with the developmental stuttering.

\section{ACKNOWLEDGMENT}

This paper has been supported by the grant project of Ministry of Education No. CEZ:J14/98:N30000018 of the Czech Republic.

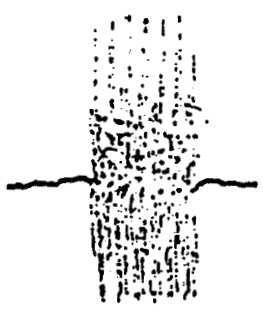

Fig. 1 Acoustic record in the prephonation phase in a healthy, nonstuttering subject registered by means of the Tesla OPD 602 oscilloscope (time base $80 \mathrm{~ms}$ ).

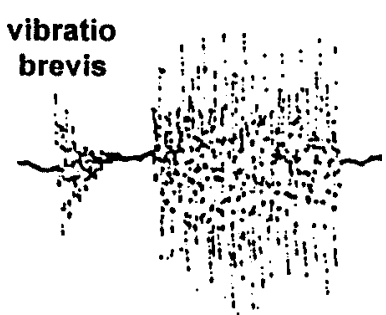

Fig. 2 Acoustic record of a typical a vibratio brevis phenomenon in the prephonation phase in a young adult stutterer (time base $80 \mathrm{~ms}$ ).

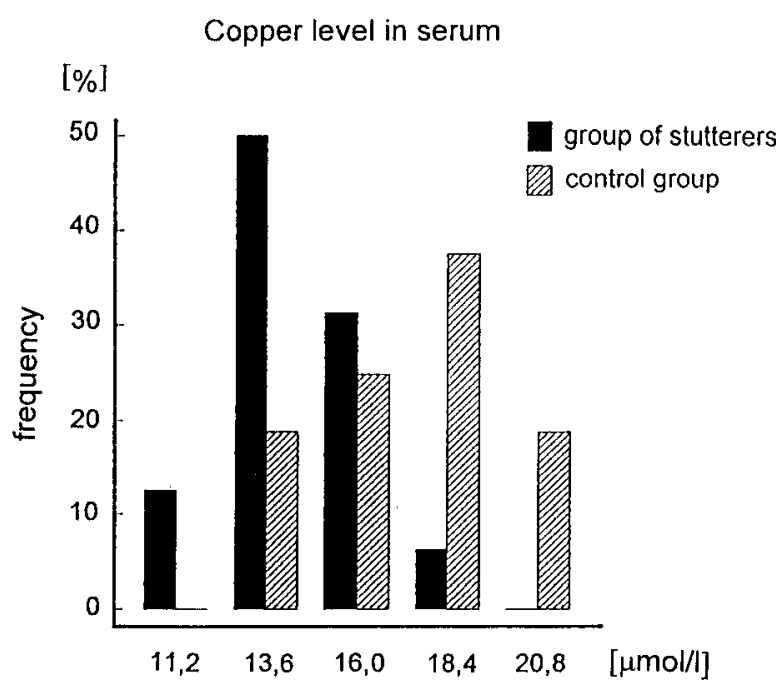

Fig. 3 The distribution of the serum copper levels in a group of stutterers $(\mathrm{n}=16)$ and in a control group of non-stuttering subjects $(\mathrm{n}=16)$.

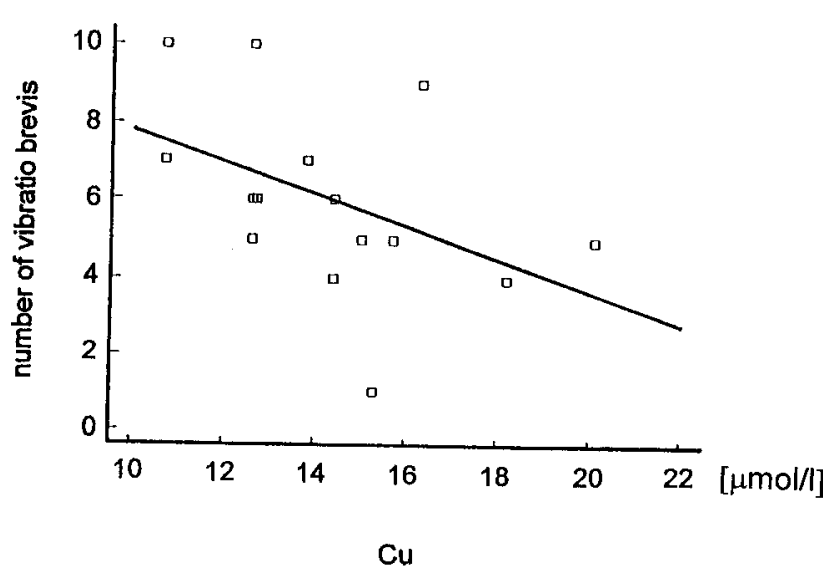

Fig. 4 Negative correlation between the blood serum copper level and the number of vibratio brevis phenomenon in a group of stutterers $(\mathrm{n}=16)$. 


\section{REFERENCES}

1. Andrews, G., Craig, A., Feyer, A.-M., Hoddinott, S., Howie, P., \& Neilson, M. (1983) Stuttering: A review of research findings and theories circa 1982. J. Speech Hear Disord 48, 226-246.

2. Bloodstein, O. (1995) A handbook on stuttering. (5th ed.). San Diego, CA: Singular Publishing Group, Inc.

3. Costa, D., Pop, A., Dumitriu, L., Marinescu, L., Antoniae, M., Marinescu, R., Boeru, L., \& Uleu, C. (1986) Serum immunoreactive parathormone levels correlate with depression and anxiety in hypocalcemic stutterers. Activ Nerv Super (Praha) 28, 155-156.

4. Fox, P. T., Ingham, R. J., Ingham, J. C., Hirsch, T. B., Downs, J. H., Martin, C., Jerabek, P., Glass, T. \& Lancaster, J. L. (1996) A PET study of the neural systems of stuttering. Nature 382, 158-162.

5. Kopp, G. A. (1934) Metabolic studies of stutterers: I. Biochemical study of blood composition. Speech Monogr. 1, 117-132.

6. Ono, S., Kurisaki, H. \& Kamakura, K. (1988) A disorder with low serum copper level, dementia, dysarthria, gait disturbance and involuntary movements. Clin. Neurol. 28, 433-436.

7. Pešák, J. \& Urbánek, K. (1993) Incoordination of the phonation start in individuals with balbuties. Fol Phoniat 45, 62-67.
8. Pool, K. D., Devous, M. D., Freeman, F. J., Watson, B. C., \& Finitzo, T. (1991) Regional cerebral blood flow in developmental stutterers. Arch Neurol 48, 509-512.

9. Rastatter, M. P. \& Harr, R. (1988) Measurements of plasma levels of adrenergic neurotransmitters and primary amino acids in five stuttering subjects: A preliminary report (biochemical aspects of stuttering). J. Fluency Disord 13, 127-139.

10. Rosenberger, P. B. (1980) Dopaminergic systems and speech fluency. J. Fluency Disord 5, 255-267.

11. Schleier, E., Schelhorn, P., \& Groh, F. (1991). Badania biochemiczne w jakaniu dzieciecym. Otolaryngol. Pol. 45, 141-144.

12. Steidl, L., Pešák, J., Chytilová, H. (1991) Stuttering and tetanic syndrome. Fol Phoniat 43, 7-12.

13. Watson, B. C., Pool, K. D., Devous, M. D., Sr., Freeman, F. J. \& Finitzo, T. (1992) Brain blood flow related to acoustic laryngeal reaction time in adult developmental stutterers. J. Speech Hear Res. 35, 555-561.

14. Willvonseder, R., Goldstein, N. P., McCall J. T., Yoss, R. E. \& Tauxe, W. N. (1973) A hereditary disorder with dementia, spastic dysarthria, vertical eye movement paresis, gait disturbance, splenomegaly, and abnormal copper metabolism. Neurology 23, 1039-1049. 